\title{
Illicit mint and unregulated vendors: constructing illegality in French public spaces
}

\author{
Roza Tchoukaleyska
}

Published in Area (2015)

\begin{abstract}
:
Focusing on street-side vending of fresh mint and herbs in the French city of Montpellier this paper considers the difference between illegal and informal vending, and the regulatory mechanisms deployed by municipal and police actors in the push to eradicate illegality. Drawing on municipal archives from the late 1990s, and interviews and city documents from the 2000s, I examine the relationship between regularized market stall holders and those selling goods outside assigned vending spaces with a particular interest in how these two groups interact, and the instances in which police and market officials are called. Through a rapidly escalating campaign to fight illegality, green fresh mint is coded as an illicit product and the individuals who sell it are targeted as dangerous criminal elements.
\end{abstract}

\section{Introduction}

Shadowed by the expansive Halles de la Paillade food market in the suburbs of the southern French city of Montpellier stand three small kiosks selling bundles of mint. Constructed from disused produce crates and wooden pallets the mint stands clump around the entrance of the Halles with piles of fragrant herbs stacked together, each wrapped in newspaper before being presented to harried clients on their way home from the week's shopping. Several tram stops away, near the city-centre Plan Cabanes plaza a series of mint stands also line the sidewalk. Their crates and cardboard boxes positioned down the street from a busy outdoor food market, the Plan Cabanes mint vendors sell newspaper wrapped bundles of fresh mint for $0.50 €$. The mint stands are in constant business and have been a regular feature of the suburban Halles de la Paillade and city-centre Plan Cabanes for many years. They are also informal, unregulated, and function outside the tightly controlled guidelines set out by the city of Montpellier's food market and public space by-laws. While nominally tolerated - and evidently well frequented by shoppers - the mint stands became the focus of municipal efforts in the mid-1990s and early 2000s when registered Halles and market vendors complained of unfair competition, resulting in police intervention.

Drawing on instances of conflict between mint vendors, police and city officials, this article will consider the regulatory mechanisms deployed by the municipality to assert influence over informal vending in public space in Montpellier. Of particular interest is the coding of a seemingly innocuous good - fresh, green mint - as an illicit and illegal product, the circumstances under which police forces intervene in public space, and the uneven municipal approach to dealing with informal vending. The article begins with an overview of informal street vending and municipal public space management as outlined in academic literature, then sets out the context and methodology of the present study, before moving on to a discussion of mint vending in Montpellier, and concluding with some comments on the meaning of 'illegality' in French public space. 


\section{Street vending and public space}

While European outdoor food markets (Holloway and Kneafsey 2000; Black 2005; Watson 2009; Spiller 2012), along with French outdoor vending (de la Pradelle 2006; Lagane 2012), have been frequently studied, the issue of informal street vending and public space conflict in Europe has been less closely examined (cf Cross 2000; Antronopoulos et al 2011; Milliot and Tonnelat 2013). Certainly a considerable literature exists on the interactions between street vending and municipal oversight beyond the European scope of this article, with Anjaria's (2006) work in Mumbai, Adaawen and Jorgensen (2012) in Accra, research in Mexico City (Pena 2000; Crossa 2009), New York City (Duneier 1999; Devlin 2011) and Hunt's (2009) work on the tensions between street sellers and state control in Bogota, amongst others (Lyons and Snoxell 2005; Donovan 2008; Bhowmik 2012). Each of these studies points to street vendors as an important element of the urban fabric, and indicate that conflicts between informal vending and state mechanisms for public space management say much about how public space is envisioned, controlled, and contested (Gaber 1994; Bromley 2000; Yatmo 2008).

The issue of how street vending and informal trading fits into European cityscapes has been addressed by several authors (Mörtenböck and Moorshammer 2007). While Fyfe et al (2006) note that street vendors may be viewed by shoppers as part of the urban incivilities that plague modern city centre (Bannister et al, 2006), in other instances they are seen to enliven plazas, creating social and cultural spaces that integrate a diversity of users (Black 2012). This duality is noted by Jones et al (2004), who indicate that street vending is both permitted and accepted in the UK, while also seen as the source of noise and unwelcome retail competition. Examining informal vending practices on the French-Italian border Hily and Rinaudo (2004) argue that popular associations between informal street sales and illegal immigration have transformed souvenir hawkers into some of the most regulated users of public space, pursued by immigration police and city officials. And while Engbersen and Van Der Leun (2001), like Hily and Rinaudo (2004), finds little substance to claims that European street traders are linked with international crime syndicates, this increasing criminalization of informal vending has altered the historic function of markets and street fairs as sites of integration for newcomers (Morales 2009).

The nuanced difference between informal and illegal - illegal meaning outside established law; informal taken as a series of socially acceptable economic practices (Meneses-Reyes and Caballero-Juárez 2013) that would normally be regulated yet function beyond state oversight (Roberts 1994; Cross and Johnson 2000) - is accentuated by van Schendel and Abraham's (2005) argument that certain vending activities can be licit and illegal at the same time. For instance, as von Lampe (2011) notes, while cigarettes are a legal good, the sale of cigarettes on the street and outside established stores makes them, effectively, illegal: sales and income taxes are not paid, the provenance of the product is not guaranteed, and there is no state oversight of vendors, supply networks and transactions. Examining street-side DVD sales in Greece, Antonopoulos et al (2001) suggest that a flutter between illegality and tacitly accepted informality is further complicated by many street vendors' links with legitimate businesses who supply the products, and thereby connecting informal vendors with established, formal businesses (Gaber 1994). What might - at least in the eyes of municipal oversight - be seen as illegal vending can be, following the arguments above, also classified as informal, indicating that the issue of illegal / informal vending is as much entangled with bylaws and legal codes as with social norms and community dynamics. 
This social aspect of vending is examined by Milliot and Tonnelat (2013) in their study of Parisian street trading. Describing a particularly violent confrontation between Parisian police and street vendors, Milliot and Tonnelat (2013) argue that the clash is indicative of competing visions of public space management: institutional order, or the municipal bylaws governing public space use (van Schandel and Abraham, 2005); and the social ordering of the street, or what Milliot and Tonnelat (2013) call 'interactional' order and Morales (2010) describes as 'self-organization'. Noting the visible and vocal anger of other street users at the Parisian vendor's arrest, Milliot and Tonnelat (2013) suggest that, in this instance, institutional order (in the form of police action) was viewed as being at odds with the informal order of public space. The manner in which street vending is regulated, contested, or accepted into the daily life of the street thus says much about how public space functions, whose interests are at stake, and how differences between institutions and social notions of city usage are negotiated.

\section{Setting the context: Montpellier's markets}

Situated in south-central France, the city of Montpellier has a population of 420.000 and has an economy build on tourism, wine production, high-tech research, and education (Volle et al 2010). In Montpellier, as in most French cities, outdoor food markets and indoor Halles are municipally managed entities that are subject to a series of health and safety, fair trading, and public space usage by-laws. Within Halles and markets the size and position of each stand is precisely defined, vendors are limited to selling only pre-approved produce - the butcher cannot deal in eggs, and the vegetable seller cannot offer jams - and all stall-holders must be selected and approved by city hall (Réglementation Générale des Halles et Marchés 2001). Second hand good and clothing cannot be sold and fundraising activity is barred without special permission, and no vendor can block the route or stand of another, shout to advertise their wares, or lend their stand to a colleague for a session. Each vendor - whether in a Halles or outdoor market - must also be in good standing with the local chamber of commerce or a professional association (for antique dealers, for instance), have a social security number, evidence of tax payments, and pay a fee for their place in the market. City officials pass through each outdoor market daily to collect vendors' fees and ensure that stalls are organized according to municipal rules, make sure occasional vendors are accommodated amongst the established outdoor market stalls, and visit the indoor Halles to meet with stallholders.

Behind the veneer of delightful chaos - colourful produce, decorative tablecloths, food samples, and permanent hum of conversation - of the shopping experience, the Halles and outdoor markets are a carefully ordered and surveilled space with the municipality acting as landlord and arbitrator of conflict while ensuring that each market day unfolds in a predictable and well-tested pattern. The Halles and markets are at once public spaces that welcomes a variety of users (de la Pradelle 2006; Cattell et al 2008) and closely regulated site with stringently enforced codes of behaviour. Within this milieu the mint vendors occupy a precarious position: they are not licensed vendors, have no formal registration with the chamber of commerce, and sell their goods outside allocated marketplaces. In the eyes of the municipality, this makes the mint vendors illegal public space users, even if the good they are selling - fresh, green mint used in cooking and for thé à la menthe (mint tea), a North African green tea with fresh mint and sugar - is legal foodstuff also sold by supermarkets and grocers. The constant stream of clients suggest that the mint vendors are both accepted as a stable facet of market life and provide a needed service not met by formal vendors (see also Cross 2000; Chang and Hsieh 2006) making them, in the vocabulary of Meneses-Reyes and 
Caballero-Juárez (2013), informal public space users who are challenging the ability of the city of Montpellier to set the terms of public space usage.

The findings outlined below are based on a year-long research project examining public space planning and urban renewal projects in Montpellier through archival research, ethnographic work, and interviews. As part of the project, I queried 'illegal vending' and 'informal public space usage' at the municipal archives, and this search returned several dossiers on 'illegal mint' (menthe à la sauvette) from the 1990s and early 2000s. The overlapping archival coding of 'illegal vending' and 'illegal mint' was intriguing - both for what it might suggest about municipal approaches to public space management, and for the meaning of 'illegality' with regards to how informal vending is managed. These municipal documents are coupled with ethnographic field notes and interview done in the mid- and late2000s with registered vendors in Montpellier's markets, during which we discussed, among other topics, the question of street vending and informal mint stalls.

\section{Montpellier's edible illegality}

The Halles de la Paillade are situated in the suburban, high-rise neighbourhood of La Mosson. The Halles are an important neighbourhood spaces that provide an affordable shopping option and also function as a social hub for the community. The Halles are open from 7am until noon every day including Sundays, a rarity in France, are accessible on public transport, and host around 35 vendors who sell fresh produce, fish, meats, breads, spices, and other foodstuff from glass-and-metal stalls. Several times a week an outdoor household goods and clothing market runs alongside the Halles, and adds a further 200 registered vendors, making the Halles and surrounding market one of the busiest shopping hubs in the city.

The municipal archival files on mint vending focus on efforts to eradicate illegal street sales around the Halles in the 1990s and early 2000s. At the time, mint stands were set up alongside the outside walls of the Halles, and also alongside other city markets. The activities of the mint vendors, along with municipal action, are well documented and include: several folder of communication between municipal officials, and municipal and national police; newspaper article clippings; meeting minutes, memos, and letters between the mayor and city and regional officials; and a series of photographs documenting a group of low wooden stands at the doors of the Halles de la Paillade, each heaped with neatly lined boxes of mint, and each manned by a single individual who is dealing with at least one customer (Archives Municipales de Montpellier (AMM) boîte 591W44).

Commencing in late 1994, the 'illegal mint' files begin with an internal memo from the city official in charges of the Halles, who notes the presence "illegal vending" in the city-centre and surrounding and arguing that it is becoming a nuisance (AMM boite 591W44 10/11/1994). The situation becomes explosive a few months later when a violent altercation between stall holders in the Halles de la Paillade and mint vendors stationed outside requires the intervention of the national police to restore calm. The illegal goods, spread out on makeshift crates and on the ground, are recorded as "fresh mint, cards, pineapples and mushrooms" (Ibid. 28/4/1995). In the memos that follow what municipal officials dub menthe à la sauvette (illegal mint) takes precedent over all other illegal goods, with a special meeting convened between several municipal committees, market and Halles representatives, and different police agencies to devise a strategy for managing the problem (Ibid. 27/10/1995). Two approaches are agreed on: increasing enforcement of public space bylaws and market regulations, through unannounced police descents alongside scheduled checks of vending 
permits by municipal officials; and a review of public space amenities outside the Halles de la Paillade, with suggestions for the shortening of the sidewalk immediately in front of the doors and removal of nearby parking spots to limit spaces of illegality.

Although the idea of physically altering public space to halt street vending had, by the late 1990s, fallen by the wayside, increased police checks were carried through - with mixed success. Although police action in the city-centre had seen street hawking of tourist-oriented souvenirs, in the suburban neighbourhood of La Paillade the mint vendors scattered at the sight of a police van only to reconvene once it was gone. By mid-1996, the issue has once again reached a crisis point, with memos between municipal and market officials noting that police involvement had become minimal, with market officials at the Halles de la Paillade arguing that they were unable to close the building on time because:

\begin{abstract}
"The municipal police are no longer coming for the mint and the illegal vegetables, the eggs and other things because of workforce limits. And when it comes to the national police, they can't be bothered with responding to these sorts of problems. Their [street vendors'] crates are invading the walkways!” (AMM boîte 591W44 06/3/1996)
\end{abstract}

Soon after the above memo, a representative from the union of market vendors sent an angry, open letter to the local newspapers accusing the municipality of wilful inaction and arguing that "the illegality and clandestine activity is killing" the markets (Ibid. 13/9/1996). The municipality responds with calls on all levels of police to fulfil their duties in terms of managing illegality in public space, and indicates that the Halles de la Paillade requires particular attention (Ibid. 07/10/1996). The documents that follow indicate that such action was not forthcoming, with a series of letters from market officials documenting the lack of response on the part of police: of 21 calls for police intervention from the Halles de la Paillade, only six resulted in any assistance in removing mint vendors (Ibid. 15/10/1996).

The above letters and memos are interesting in several respects. First, they indicate that the majority of complaints about mint vendors and street hawkers come from formally registered stallholders, and that residents and shoppers are rarely noted as finding the presence of mint vendors a problem. Further, the challenge of mint vendors and street traders is frequently frames as one of economics: they present unfair competition by drawing in Halles clients, and have an unfair advantage because they do not pay market dues and registration fees. Police and municipal officials, meanwhile, seem hesitant - or perhaps limited in their capacity - to respond, and it is only in the late-1990s that a new strategy for dealing with street vending is devised.

Starting in 1997, the issue is less frequently frames as one of illegal vendors and more often one of 'illegal mint' (menthe à la sauvette). The subtle change in vocabulary marks the start of a different form of police intervention in public space: the focus is on mint vendors as an organized commercial network with links across the city and region, and their infringement on public space a serious question of illegal activity threatening formally organized food markets (AMM boîte 591W44 24/6/1997-06/3/2000). Starting in 1997, a series of police descents on the Halles de la Paillade result in the seizure of several kilograms of mint (Ibid. 24/8/1997) and many vendors taken into custody for identity checks, with municipal police recording work permit numbers and foreign national details. Although all mint vendors are ultimately released (Ibid. 25/6/1997), in a report municipal police note their particular frustration at not only finding these same individuals selling mint at the Halles de la Paillade 
the following week - but also the vendors' refusal to reveal the names of their mint suppliers (Ibid. 8/7/1997). Tangential interactions between municipal and state officials and mint vendors continue with letters describing the situation as rapidly degrading, and renewed calls for further cooperation between police and state agencies (Ibid. 08/6/1998-28/10/99). Following a 1998 descent on the Halles de la Paillade, police note that youth are seen selling mint on the sly around the Halles while adults supervise from parked cars (Ibid., 08/7/1998) while during another police action a scuffle between police and mint vendors results in a one vendor falling "nose straight into the mint" (Ibid. 08/6/1998) while trying to run away. In 2000 the Halles de la Paillade are again singled out as the main sites of illegal vending, with mint noted as being particularly difficult to erase (Ibid. 06/3/2000-29/3/2000). The DeputyMayor goes on to engage the regional fraud detection unit, with a memo that suggests that the mint networks "appear to be supplied by one or more providers who function in a highly organized manner" (Ibid. 06/3/2000), with notes describing a "cat and mouse" (Ibid. handwritten note) game between illegal mint sellers, registered vendors and city officials at the Halles de la Paillade.

While in 1994, at the start of the 'illegal mint' files, the issue is described as one of street vendors usurping clients and profits from established market stall holders and infringing on public space laws, by 2000s the topic has been reframed into one of unannounced police descents on the Halles de la Paillade, the use of a fraud detection unit, and a vocabulary of suppliers, lookouts, and a scenario in which fresh, green mint is re-coded as a dangerous, uncontrollable substance. The latter description of mint - where the mint itself is depicted as illegal, and not just the vending - mirrors some of the vocabulary used to describe illegal drug cartels (cf. Brown 2007). In the process, the focus ceases to be on public space management, and instead becomes an issue of illegality-versus-police enforcement, with municipal documents outlining a series of verbal and physical confrontations between police and mint sellers.

This result is, perhaps, all the more surprising when juxtaposed with other outdoor markets and their associated street vendors in Montpellier. If the pursuit of sidewalk sales at the Halles de la Paillade requires considerable municipal resources, at the city-centre Plan Cabanes neighbourhood a very different mechanism has emerged: the mint sellers (set-up near the tramway) and registered vendors of the market (two blocks west of the tramway) have situated themselves roughly 200 meters apart, through an unofficial division of plazas and streets that is understood by both sides to reduce direct competition. "It's been a while that they've been over there" noted one of Plan Cabanes' produce sellers in an interview, gesturing towards the five wooden stands propped up against the stone walls of a department store in the distance. The mint sellers and their crates rarely encroach on the market plaza, and if they do they are swiftly talked out of setting up their stands. The vendors of Plan Cabanes have asserted an influence and authority over the market and its sidewalks that extends a limited tolerance to mint stands, who in turn keep their distance - a form of public space self-organization (cf Morales 2010; de la Pradelle 2006). As a result the municipality is not called upon to deal with mint sellers by the registered vendors, and unlike the Halles de la Paillade, the national and municipal police take a minimal interest in enforcing public space bylaws - although, as several vendors noted, municipal police are very much present and efficient in handing out parking fines in the area. Further, as Faure (1998) notes, sidewalk mint sales in the Plan Cabanes are neatly incorporated into entrepreneurial networks with shoppers showing loyalty to their preferred mint stand. As a result there are few hints of catand-mouse games with police, no suggestions of mint-cartels supplied by well organized networks, nor constant complaints from vendors and municipal officials. The mint vendors 
and regularized stall holders exist in a mutually defined symbiosis that allows the market to function with relative autonomy from municipal oversight.

\section{Conclusions:}

The situation of mint vendors at the Plan Cabanes and Halles de la Paillade reveals two forms of public space organization: while around the Plan Cabanes plaza formal vendors and mint sellers have reached an informal agreement, at the Halles de la Paillade this sort of cooperation between registered and unregistered vendors does not exist. As the extensive effort to eradicate mint sales around the Halles de la Paillade in the 1990s and early 2000s indicate, internal concessions between different types of vendors had broken down, with registered stall holders vocally demanding that the state exercise its authority over the market and surrounding public space, creating a flurry of documentation on illegality and market infringements. It is as a result of this additional attention - police checks, vending permit controls, descents by the frauds detection unit of the municipal office - that street-side mint sales shift from an informal activity to an illegal one at the Halles de la Paillade. Illegality is, in other words, a status produced through the diligence of a distinct group of users: in this case Halles de la Paillade vendors complaining about mint sales, and municipal and police acting on those complaints. Although the Halles de la Paillade and surroundings are subject to extensive public space bylaws, these spaces become closely regulated only when, and if, the municipal bodies charged with enforcing those rules are pushed into action. The results of state intervention and municipal regulation are stark. The criminalization of an otherwise everyday good through the notation of 'menthe à la sauvette' (illegal mint) and notation of herbal-cartels and organized mint suppliers suggests an unprecedented degree of lawlessness.

The municipality's ability to assert an influence over markets, public spaces and sidewalks is thus seemingly limited when shoppers, residents and vendors shy away from pursuing informal infractions. At Montpellier's Plan Cabanes plaza mint vendors are integrated into a neighbourhood shopping hub, and through informal modes of public space organization (van Schandel and Abraham, 2005; Morales 2010) function in symbiosis with registered vendors. The seeming municipal and police complacency with respect to mint vending in the Plan Cabanes hints at a reluctance to chase informal vending in the absence of complaints. Although Montpellier's municipal bylaws suggest that public space and the city's indoor Halles and outdoor markets are carefully regulated sites, the reality of market life and street vending suggests that public space is, in fact, more flexible and less controlled than imagined. Rather than institutional order governing how public space is used (Milliot and Tonnelat 2013), the case of Montpellier's mint vendors indicates that it is social norms and customs or the collapse of these, as at the Halles de la Paillade - and the actions of public space users which determine how informal vendors are viewed and integrated into the urban landscape.

\section{References:}

Adaawen S and Jorgensen S 2012 Eking out a living: the livelihood implications of urban space regulation on street hawking in Accra, Ghana African Review of Economics and Finance 3 49-95

Anjaria J S 2006 Street hawkers and public space in Mumbai Economic and Political Weekly 41 2140-46 
Antonopoulos G A, Hobbs D and Hornsby R 2011 A soundtrack to (illegal) entrepreneurship: pirated CD/DVD selling in a Greek provincial city British journal of criminology $51804-22$

Archives Municipales de Montpellier Côte 591W44 Manifestation commerciales et marchés - Marché de la Paillade, réglementation: documents sur les vendeurs à la sauvette (10/11/94 $-29 / 3 / 00)$

Bannister J, Fyfe N and Kearns A 2006 Respectable or respectful? (In)civility and the city Urban studies 43 919-37

Bhowmik S ed 2012 Street vendors in the global urban economy Routledge, New Delhi Black R 2005 The Porta Palazzo farmers' market: local food, regulations and changing traditions Anthropology of food [online] 4 May (http://aof.revues.org/index157.html) Accessed 11 January 2012

Black R 2012 Porta Palazzo: the anthropology of an Italian market University of Pennsylavania Press, Philadelphia

Bromley R 2000 Street vending and public policy: a global review International journal of sociology and social policy 20 1-29.

Brown M 2007 Mapping discursive closings in the war on drugs Crime Media Culture 311 29

Cattell V, Dines N, Gesler W and Curtis S 2008 Mingling, observing, and lingering: everyday public spaces and their implications for well-being and social relations Health and place 14 544-61

Chang J and Hsieh A-T 2006 Leisure motives of eating out in night markets Journal of business research 59 1276-78

Cross J 2000 Street vendors, modernity and postmodernity: conflict and compromise in the global economy International journal of sociology and social policy 20 30-52

Cross J and Johnson B 2000 Expanding dual labour market theory: crack dealers and the informal sector International Journal of Sociology and Social Policy 20 96-134

Crossa V 2009 Resisting the entrepreneurial city: street vendors' struggle in Mexico City's historic centre International Journal of Urban and Regional Research 33 43-63

de la Pradelle M 2006 Market day in Provence University of Chicago Press, Chicago

Devlin R T 2011 'An area that governs itself': informality, uncertainty and the management of street vending in New York City Planning Theory 10 53-65

Donovan M G 2008 Informal cities and the contestation of public space: the case of Bogotá's street vendors, 1988-2003 Urban Studies 45 29-51

Duneier M 1999 Sidewalk. New York, Farrar Straus and Giroux 
Engbersen G and Van Der Leun $\mathbf{J} 2001$ The social construction of illegality and criminality European journal of criminal policy and research 9 51-70

Faure P 1998 Un quartier de Montpellier: Plan Cabanes, étude ethnologique L'Harmattan, Paris

Fyfe N, Bannister J and Kearns A 2006 (In)civility and the city Urban studies 43 853-61

Gaber J 1994 Manhattan's 14 ${ }^{\text {th }}$ Street vendors' market: informal street peddlers' complementary relationship with New York City's economy Urban Anthropology 23 373408

Hily M-A and Rinaudo C 2004 L'expérience des vendeurs migrants sur le marché de Vintimille Revue française des affaires sociales 2 165-80

Holloway L and Kneafsey M 2000 Reading the space of the farmers' market: A preliminary investigation from the UK Sociologia Ruralis 40 285-99

Hunt S 2009 Citizenship's place: the state's creation of public space and street vendors' culture of informality in Bogotá, Colombia Environment and Planning D: Society and Space $27331-51$

Jones P, Comfort D and Hillier D 2004 The regulation of street trading in the UK Geography 89 248-53

Lagane J 2012 L'essor des marchés paysans à Marseille. Entre pratique de communication citoyenne et écologisation. Questions de communication [online] 22 (http://questionsdecommunication.revues.org/6936) Accessed 21 May 2014

Lyons M and Snoxell S 2005 Sustainable urban livelihoods and marketplace social capital: crisis and strategy in petty trade Urban Studies 42 (8) 1301-20

Meneses-Reyes R and Caballero-Juárez J A 2013 The right to work on the street: public space and constitutional rights Planning Theory [online] 19 September 2013 (http://plt.sagepub.com/content/early/2013/09/18/1473095213503967) Accessed on 21 May 2014

Milliot V and Tonnelat S 2013 Contentious policing in Paris: the street as a space for emotional public solidarity in Lippet $\mathbf{R} \mathbf{K}$ and Walby $\mathbf{K}$ eds Policing cities: urban securitization and regulation in a $21^{\text {st }}$ century world Routledge, Abingdon 191-204

Morales A 2009 Public markets as community development tools Journal of planning education and research 28 426-40

Morales A 2010 Planning and the self-organization of marketplaces Journal of Planning Education and Research 30(2) 182-197

Mörtenböck P and Mooshammer H 2007 Trading indeterminacy - informal markets in Europe Field: A free journal for architecture 1 73-87 
Pre-print version

Pena S 2000 Regulating informal markets: informal commerce in Mexico City International Journal of Sociology and Social Policy 20 37-67

Réglementation Générale des Halles et Marchés Ville de Montpellier Direction de la Réglementation Publique: Service des Affaires Commerciales. Montpellier November 16, 2001

Roberts B 1994 Informal economy and family strategies International journal of urban and regional research 18 6-23

Spiller K 2012 It tastes better... consumer understandings of UK farmers' market food Appetite 59 100-107

Van Schendel W and Abraham I 2005 Introduction: the making of illicitness in van Shendel W and Abraham I eds Illicit flows and criminal things: states, borders and the other side of globalization Indiana University Press, Bloomington 1-37

Volle J-P, Viala L, Négrier E and Bernié-Boissard, $\mathbf{C}$ eds Montpellier: la ville inventée Marseille, Edition Parenthèse / Gip Epau

Von Lampe K 2011 The illegal cigarette trade In: Natarajan M ed International Criminal Justice Cambridge University Press, New York 148-54

Watson S 2009 The magic of the marketplace: sociability in a neglected public space. Urban Studies 46 1577-91

Yatmo Y 2008 Street vendors as 'out of place' urban elements Journal of urban design 13 $387-402$ 